\title{
A Review of Biochemical Process of Anaerobic Digestion
}

\author{
Kayode Feyisetan Adekunle*, Jude Awele Okolie \\ Department of Chemical Engineering, College of Engineering and Engineering Technology, Michael Okpara \\ University of Agriculture, Umudike, Nigeria \\ Email: ${ }^{*} \mathrm{k}$ adekunle@yahoo.co.uk
}

Received 7 March 2015; accepted 21 March 2015; published 26 March 2015

Copyright (C) 2015 by authors and Scientific Research Publishing Inc.

This work is licensed under the Creative Commons Attribution International License (CC BY).

http://creativecommons.org/licenses/by/4.0/

(c) (i) Open Access

\begin{abstract}
The search for alternative energy and fuels has motivated researchers to focus on renewable and sustainable means of getting them instead of relying on the conventional way of energy and fuel production. Anaerobic digestion is a biochemical process during which complex organic matter is decomposed in absence of oxygen, by various types of anaerobic microorganisms. The process of Anaerobic digestion is appropriate for all waste water treatment systems given that the solid can be introduced to the system at an acceptable concentration. Biogas, the product of anaerobic digestion process is a clean and renewable form of energy which can be a substitute for conventional sources of energy which are causing ecological-environmental problems and the same time depleting at a faster rate. This paper reviews the anaerobic digestion process and its complexities; it covers different stages involved in the process, the substrate used in the process, the relationship between the substrate and microorganisms and important operating parameters such as $\mathrm{pH}$, temperature and loading rate.
\end{abstract}

\section{Keywords}

Anaerobic Digestion, Biogas, Municipal Solid Waste, Waste Management, Microorganism

\section{Introduction}

The need to develop and improve sustainable energy resources is eminent due to the finite nature of our fossil fuels [1]. The use of fossil fuels as the main source of energy has caused several economic and environmental challenges [2]. Many of the rural communities in developing countries are forced to rely on the traditional energy sources such as firewood, crop residues and paraffin. These traditional methods are often expensive, not

"Corresponding author. 
eco-friendly and time consuming [3]-[5]. Cooking accounts for 90\% of energy consumption in the household of developing countries [6], further more access to electricity in rural areas is relatively scarce [7]. Biogas is a substitute for firewood and cattle dung that can meet the energy needs of the rural population [8]. Biogas is a combustible gas consisting mainly of methane, carbon dioxide and small amount of other gases and trace elements, it is an environment friendly, economic and alternate means to fossils such as firewood and coal. In many countries biogas is used nowadays for combined heat and power generation (CHP) or it is upgraded and fed into natural gas grids, used as vehicle fuel or in fuel cells [9]. The ultimate methane yield is affected by several factors, such as the feed, species, breed and growth stage of the animals as well as the amount and type of the bedding materials together with the pre storage conditions prior to biogas production [10]. The composition, i.e., the protein, fat, fiber, cellulose, hemicellulose, starch and sugar content, are also important factors that influence the methane yield [11].

Anaerobic digestion is a suitable technology to treat solid waste and waste water and it has been considered as a waste to energy technology. Major progress was made in all areas of waste management but the introduction of anaerobic digestion into the treatment of municipal solid waste is one of the most successful and innovative technology developments observed during the last two decades in the waste management field [12]. Anaerobic digestion has become fully accepted as a proven and an even preferred method for the intensive biodegradation phase of organic fractions derived from municipal solid waste. The production of biogas through anaerobic digestion offers significant advantages over other forms of bioenergy production. Limitation of carbon dioxide and other emission through emission regulations, carbon taxes and subsides on biomass energy is making anaerobic digestion a more attractive and competitive technology for waste management. There is an abundant availability of cellulose based waste, which could be appropriate for biogas production e.g. lignocellulose and waste textiles. These materials are carbohydrate rich and could be used as a substrate for biogas production. However, the recalcitrance nature of these substrates makes them very difficult to digest, as their structure opposes microbial hydrolysis in biogas production [13] [14]. Today, the application of lignocellulose materials in biogas production is limited and for waste textiles, it is nonexistent [13] [14]. Production of biogas from AD requires work power for production, collection and transport of AD feedstock, manufacture of technical equipment, construction, operation and maintenance of biogas plants. This means that the development of a national biogas sector contributes to the establishment of new enterprises, some with significant economic potential, increases the income in rural areas and creates new jobs.

\section{Anaerobic Digestion}

Anaerobic digestion is gaining more attention nowadays, both as a solution to environmental concerns and also as an energy resource for today's energy-demanding life style [15]. With a total of 244 plants and a capacity of almost 8 million ton of organics treatment capacity, anaerobic digestion is already taking care of about $25 \%$ of the biological treatment in Europe [12]. In anaerobic digestion, organic materials are degraded by bacteria, in the absence of oxygen, converting it into a methane and carbon dioxide mixture. The digestate or slurry from the digester is rich in ammonium and other nutrients used as an organic fertilizer [3] [16]-[20]. Microorganism from two biological kingdoms, the bacteria and the archaea carry out this process in strict anaerobic conditions [21] [22].

Anaerobic digestion of organic waste is of increasing interest as it offers an opportunity to deal with some of the problems regarding the reduction of the amount of organic waste, while diminishing environmental impact and facilitating a sustainable development of the energy supply [23]. Even though continued progress has been made with other alternative treatment technologies (gasification, pyrolysis, plasma, biological drying, etc.), these technologies have by far not seen the same widespread implementation that anaerobic digestion has been able to achieve. In Europe alone, 244 installations dealing with the organic fraction of municipal solid waste as a significant portion of the feedstock have been constructed or are permitted and contracted to be constructed (up to 2014) [12]. There are many cases of anaerobic digestion systems applied in the agricultural sector at animal feeding operations and diaries to alleviate some of the impacts of manure and for energy production [24]. The majority of these anaerobic digestion systems in operations are single stages, in a single stage (one stage), all of the biological reactions occur within a single reactor or holding tank. There are studies that two-stage anaerobic digestion could provide great advantages over the single-stage digestion due to a more rapid and more stable treatment achieved [12]. In practice however, it is argued that the two-stage digestion has not been able to vali- 
date its claimed advantages in the market, and the added benefits in increasing the rate of hydrolysis and methanization have not been confirmed [25]. Industrial applications therefore have displayed little acceptance for twostage systems so far [26].

\subsection{The Anaerobic Digestion Process}

Anaerobic digestion is often considered to be a complex process, the digestion itself is based on a reduction process consisting of a number of biochemical reactions taking place under anoxic conditions [27]. Methane formation in anaerobic digestion involves four different steps: hydrolysis, acidogenesis, acetogenesis, and methanogenesis. Generally in an anaerobic digestion process, the rate limiting step can be defined as the step that causes process failure under imposed kinetic stress [27]. In other words, in a contex of a continuous culture, kinetic stress is defined as the imposition of a constantly reducing value of the solids retention time until it is lower than the limiting value; hence it will result in a washout of the microorganism [28]. Most researchers report that the rate-limiting for complex organic substrate is the hydrolysis step [29]-[35] due to the formation of toxic byproducts (complex heterocyclic compounds) or non-desirable volatile fatty acids (VFA) formed during hydrolysis step [36] [37]: whereas methanogenesis is the rate limiting step for easy biodegradable substrates [36] [38]-[40]. The anaerobic digestion process can be divided into two phase as illustrated in Figure 1.

The microorganism carrying out the degradation reactions in each of these phases differ widely regarding physiology, nutritional needs, growth kinetics, and sensitivity to environment. Very often, it is difficult to keep a delicate balance between these two groups: the acid forming and the methane forming microorganisms, which lead to reactor instability and consequently low methane yield [41]. The two main groups of microorganisms could be physically separated with the intention of making use of the difference in their growth kinetics [25]. In order to accomplish phase separation, several techniques have been employed such as membrane separation, kinetic control, and $\mathrm{pH}$ control [42]-[46].

\subsubsection{Hydrolysis}

This is the first step in anaerobic digestion process, it involves the enzyme-mediated transformation of insoluble organic materials and higher molecular mass compounds such as lipids, polyssacharides, proteins, fats, nucleic acid etc. into soluble organic materials i.e. to compounds suitable for the use as source of energy and cell carbon such as monosaccharides, amino acids and other simple organic compounds. This step is carried out by strict anaerobes such as bacterides, clostridia and facultative bacteria such as streptococci etc. [1]. This first stage is very important because large organic molecules are simply too large to be directly absorbed and used by microorganisms as a substrate/food source. To accomplish biodegradation, certain microorganisms secrete different types of enzymes, called extracellular enzymes, which "cut" the larger molecules up into smaller pieces that the microorganism can then take into the cell and use as a source of energy and nutrition. Some microorganisms secrete several different enzymes, which allow them to break down different types of organic materials. Other microorganisms are specialised. For example, they secrete enzymes that break down either sugar or protein. Microorganisms that break down different sugars are called saccharolytic, while those that break down proteins are called proteolytic. There are different enzymes for sugars, proteins, fats etc. [48]. Table 1 contains examples of some different groups of extracellular enzymes. Each group contains several enzymes that are specialised in various substrates, such as different proteins. The rate of decomposition during the hydrolysis stage depends greatly on the nature of the substrate. The transformation of cellulose and hemicellulose generally takes place more slowly than the decomposition of proteins [48].

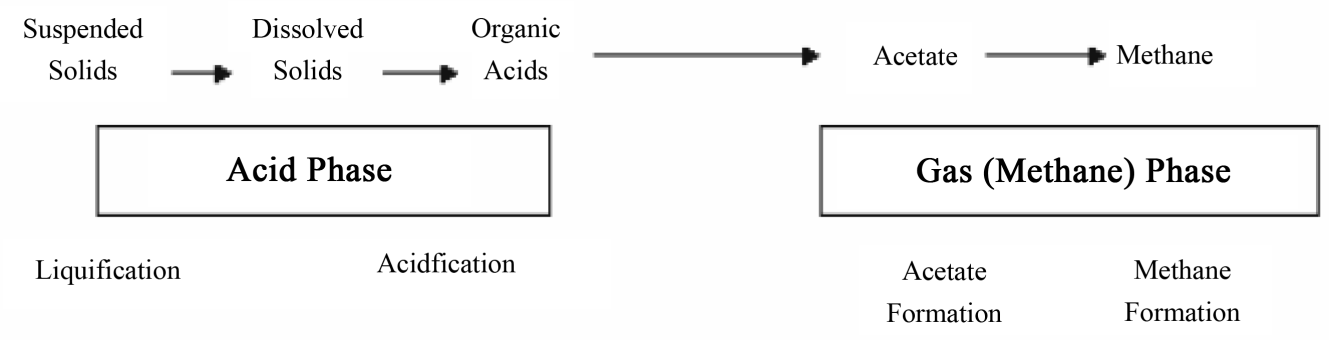

Figure 1. Phase separation of the anaerobic digestion system. Adapted from [47]. 
Table 1. Some important groups of hydrolytic enzymes and their functions [48].

\begin{tabular}{ccc}
\hline Enzymes & Substrates & Breakdown products \\
\hline Proteinase & Proteins & Amino acids \\
Cellulase & Cellulose & Cellobiose and glucose \\
Hemicellulase & Hemicellulose & Sugars, such as glucose, xylose, mannose and arabinose \\
Amylase & Starch & Glucose \\
Lipase & Fats & Fatty acids and glycerol \\
Pectinase & Pectin & Sugars, such as galactose, arabinose and polygalacticuronic acid \\
\hline
\end{tabular}

\subsubsection{Acidogenesis}

The monomers produced in the hydrolytic phase are taken up by different facultative and obligatory anaerobic bacteria and are degraded further into short chain organic acids such as butyric acids, propanoic acids, acetic acids, alcohols, hydrogen and carbon dioxide. The concentration of hydrogen formed as an intermediate product in this stage influences the type of final product produced during the fermentation process. For example, if the partial pressure of the hydrogen were too high, it would decrease the amount of reduced compounds. In general, during this phase, simple sugars, fatty acids and amino acids are converted into organic acids and alcohols [49].

\subsubsection{Acetogenesis}

The products produced in the acidogenic phase are consumed as substrates for the other microorganisms, active in the third phase. In the third phase, also called the acidogenic phase anaerobic oxidationare performed [27]. Products which cannot be directly converted to methane by methanogenic bacteria are converted into methanogenic substrates, volatile fatty acids and alcohols (VFA) are oxidized into methanogenic substrates like acetate, hydrogen and carbon dioxide, VFA with carbon chains longer than one unit are oxidized into acetate and hydrogen [9]. It is important that the organisms which carry out the anaerobic oxidation reactions collaborate with the next group, the methane forming microorganisms; this collaboration depends on the partial pressure of the hydrogen present in the system. Under anaerobic oxidation, protons are used as the final electron acceptors which lead to the production of $\mathrm{H}_{2}$. However these oxidation reactions can only occur if the partial pressure of hydrogen is low, which explains why the collaboration with the methanogens is very important since they will continuously consume the $\mathrm{H}_{2}$, to produce methane. Hence during this symbiotic relationship inter-species hydrogen transfer occurs [48] [50]-[52].

\subsubsection{Methanogenesis}

In the methanogenic phase, the production of methane and carbon dioxide from intermediate products is carried out by methanogenic bacterial under strict anaerobic conditions [27]. Methanogenesis is a critical step in the entire anaerobic digestion process as it is the slowest biochemical reaction of the process [9]. Figure 2 shows the whole biochemical process.

\section{Substrate for Anaerobic Digestion Process}

A wide range of biomass types can be used as substrate (feedstock) for the production of biogas from anaerobic digestion process. The substrate should meet the nutritional requirements of the microorganisms regarding the energy sources and various components vital for building new cells. The substrate should also include a wide variety of components necessary for the activity of microbial enzymes systems such as trace elements and vitamins [27]. Substrate composition is important in the anaerobic digestion process. The composition ultimately also affects the quality of the digestion residue (digestate), both in terms of plant nutrient content and potential contamination (metals, organic compounds, disease-causing organisms, etc.). Choosing the right material gives you the opportunity to influence the outcome of the process, maximise energy output and produce biofertilizer of good quality.

The most common biomass used in European Biogas plant production are listed below:

- Animal manure and slurry;

- Agricultural residues and by products; 


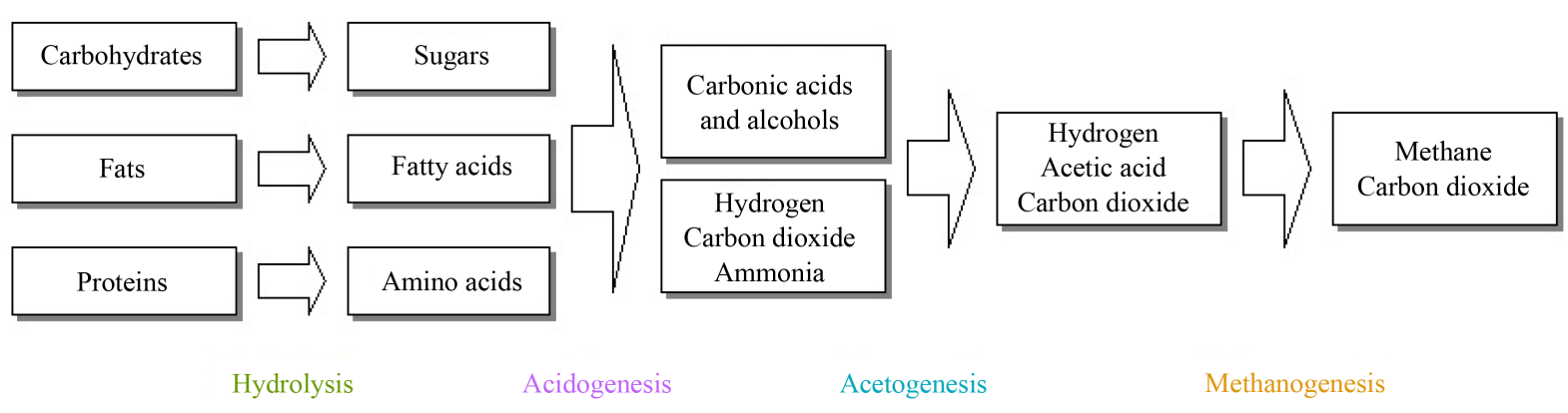

Figure 2. The key process stages of anaerobic digestion [9].

- Digestable organic wastes from food and agro industries (vegetable and animal origin);

- Organic fraction of municipal waste and from catering;

- Sewage sludge;

- Dedicated energy crops (e.g. maize, miscanthus, sorghum).

\section{The Importance of Substrate for Microorganisms}

The composition of a substrate is very important for the microorganisms in the biogas process and thus also for process stability and gas production. When it comes to the decomposition of organic material in the anaerobic digestion process, the ratio of carbon to nitrogen (C/ $\mathrm{N}$ ratio) is also regarded to be of great importance, therefore the performance of the anaerobic digestion process is shown to be enhanced by using substrates from different sources and with the right proportions [53]. Investigations show that co-digestion of substrates from different sources produces more gas than predicted compared to gas production from the individual substrate [23] [54] [55].

It is hard to say exactly what ratio is optimal because it varies with different substrates and also with the process conditions. Several factors affect the optimum $\mathrm{C} / \mathrm{N}$ ratio for such a process:

1) If the substrate is limited by factors other than the amount of carbon or nitrogen, for example, low levels of phosphorus and trace elements. This can have an effect on the function of the process which becomes more important than the $\mathrm{C} / \mathrm{N}$ ratio.

2) Process decomposition efficiency. If the degree of decomposition in the process (i.e. the proportion of the organic material that is converted to methane), is low, a smaller portion of nitrogen is released as ammonia compared to a process with a high degree of decomposition. Such a process "handles" a substrate with a low $\mathrm{C} / \mathrm{N}$ ratio better than a process with more efficient degradation.

3) The composition of the substrate (i.e. which components are actually responsible for the $\mathrm{C} / \mathrm{N}$ ratio). Long-chain carbon compounds, such as cellulose, are broken down slowly, and the risk of acidification of the process is significantly lower than where most of the carbon is glucose, which degrades very quickly. Some of the carbon can also occur in the form of lignin, which in its intact form does not decompose at all during the process [56].

It is also preferable to use a substrate that is not too diluted, that is, contains too much water in relation to the amount of organic substrate. If the material is too diluted, and contains too little organic matter, the risk is that microorganisms are washed out in a continuous process. This is because their growth rate is low. The preferred water content depends on the type of process used. A highly diluted material can be treated by various techniques to retain the microorganisms, for example, using a carrier material or adding back biomass [57] [58].

\section{Digestion Factors}

Anaerobic digestion depends on several different parameters for an optimum performance. Different groups of microorganisms are involved in the methane production, and suitable conditions have to be established to keep all the microorganisms in balance. Some of these parameters are: $\mathrm{pH}$, temperature, mixing, substrate, $\mathrm{C} / \mathrm{N}$ ratio, and hydraulic retention time (HRT) [27]. Digestion is a slow process and it takes at a minimum of three weeks for the microorganisms to adapt to a new condition when there is a change in substrate or temperature [51]. A symbiotic relationship is necessary between the hydrogen-producing acetogenic microorganisms and the hydro- 
gen-consuming methanogens. Furthermore, a neutral $\mathrm{pH}$ is favorable for biogas production, since most of the methanogens grow at the $\mathrm{pH}$ range of 6.7 - 7.5. Temperature is also an important factor in the biogas production. Most of the acid forming microorganisms grows under mesophilic conditions; however, for methanogens, a higher temperature is favorable [51]. Mixing is also an essential parameter for biogas production. Too much mixing stresses the microorganisms and without mixing foaming occurs. Methane-forming microorganisms grow slowly, with a doubling time of around 5 - 16 days. Therefore, the hydraulic retention time should be at least 10 - 15 days, unless these bacteria are retained by, for example, entrapment. Substrate and the balance of carbon sources with other nutrients such as nitrogen, phosphorus, and sulfur is also important. The substrate should be slowly digested; otherwise easily degradable substrates may cause a sudden increase in acid content. The carbon and nitrogen ratio should be around 16:1 - 25:1. Too much increase or decrease in the carbon/nitrogen ratio affects biogas production. The concentration of solids in the digester should vary between $7 \%$ and $9 \%$. Particle size is not an important factor compared to other parameters such as $\mathrm{pH}$ and temperature. However, the size of the particles used affects the degradation and ultimately the biogas production rate [23] [49] [51].

\section{Conclusion}

The growing global concerns on the increasing amount of waste, global warming and a reliance on fossil fuels as the main energy source have stimulated research on the anaerobic digestion process and its complexities. A critical analysis of literature reveals that the anaerobic digestion process is the principal source of biogas production. In comparison with other biofuels, in biogas production a wide range of substrate can be utilized as long as they are biodegradable. The use of certain substrate for the process depends on the ability of the substrate to meet the nutritional requirements of the microorganism. Hence substrate composition is very important in the anaerobic digestion process. Bioenergy will be the most significant renewable energy source because it offers an economical attractions and alternatives to fossil fuels. Anaerobic digestion has many advantages because of its low consumption of energy, low sludge production, smaller space requirements, reduction in waste volume and the production of biofertiliser and valuable soil conditioners.

\section{References}

[1] Merlin Christy, P., Gopinath, L.R. and Divya, D. (2014) A Review on Anaerobic Decomposition and Enhancement of Biogas Production through Enzymes and Microorganisms. Renewable and Sustainable Energy Reviews, 34, 167-173. http://dx.doi.org/10.1016/j.rser.2014.03.010

[2] Budiyono, Widiasa, I.N., Johari, S. and Sunarso (2010) The Kinetic of Biogas Production Rate from Cattle Manure in Batch Mode. International Journal of Chemical and Biomolecular Engineering, 3, 39-44.

[3] NAS (1977) Methane Generation from Human. Animal and Agricultural Waste; National Academy of Sciences, Washington DC.

[4] Ravindanath, N.H. (2000) Renewable Energy and Environment: A Policy Analysis for INDIA: Tata. Mcgraw-Hill, Pradesh.

[5] Zhang, J., Mauzerall, D.L., Zhu, T., Liang, S., Ezzah, M. and Remais, J.V. (2010) Environmental Health in China: Progress towards Clean Air and Safe Water. Lancet, 375, 1110-1119. http://dx.doi.org/10.1016/S0140-6736(10)60062-1

[6] Bioenergylists. http://www.stoves.Bioenergylists.Org

[7] Luijten, C.C.M. and Kerkhof, E. (2011) Jatropha Oil and Biogas in a Dual Fuel Combustion Engine for Rural Electrification. Energy Conversion and Management, 52, 1426-1438.

[8] Bhattacharya, S.C., Abdul Salam, P. and Sharma, M. (2000) Emissions from Biomass Energy Use in Some Selected Asian Countries. Energy, 25, 169-188. http://dx.doi.org/10.1016/S0360-5442(99)00065-1

[9] Al Seadi, T., Ruiz, D., Prassl, H., Kottner, M., Finsterwaldes, T., Volke, S. and Janssers, R. (2008) Handbook of Biogas. University of Southern Denmark, Esbjerg.

[10] Moller, H.B., Sommer, S.G. and Ahring, B.K. (2004) Methane Productivity of Manure Straw and Solid Fractions of Manure. Biomass and Bioenergy, 25, 485-495. http://dx.doi.org/10.1016/j.biombioe.2003.08.008

[11] Comino, E., Rosso, M. and Riggio, V. (2009) Development of a Pilot Scale Anaerobic Digester for Biogas Production from Cow Manure and Why They Mix. Bioresource Technology, 100, 5072-5078. http://dx.doi.org/10.1016/j.biortech.2009.05.059

[12] De Baere, L. (2000) Anaerobic Digestion of Solid Waste: State of the Art. Water Science and Technology, 41, 283- 
290.

[13] Jeihanipour, A. (2011) Waste Textiles Bioprocessing to Ethanol and Biogas. Doctoral Thesis, Chalmers University of Technology, Gothenburg.

[14] Teghammar, A. (2013) Biogas Production from Lignocelluloses: Pretreatment, Substrate Characterization, Co-Digestion and Economic Evaluation. Doctoral Thesis, Chalmers University of Technology, Gothenburg.

[15] Asam, Z.U.Z., Poulsen, T.G., Nzami, A-S., Raxique, R., Kiely, G. and Murphy, J.D. (2011) How Can We Improve Biomethane Production Per Unit of Feedstock in Biogas Plant. Applied Energy, 88, 2013-2018. http://dx.doi.org/10.1016/j.apenergy.2010.12.036

[16] Meynell, P.J. (1976) Methane: Planning a Digester. Sochen Books, Prison Stable Court, Dorset, Clarington.

[17] Santerre, M.T. and Smith, K.R. (1982) Measures of Appropriateness. The Resource Requirements of Anaerobic Digestion (Biogas) System. World Development, 10, 239-261. http://dx.doi.org/10.1016/0305-750X(82)90013-4

[18] Sathianathan, M.A. (1975) Biogas Achievements and Challenges. Association of Voluntary Agencies for Rural Development, New Delhi.

[19] Singh, R.B. (1973) Bio-Gas Plant: Design with Specifications. Gober Gas Plant Research Station, Ajitmal.

[20] Singh, R.B. (1974) Bio-Gas Plant: Generating Methane from Organic Wastes. Gober Gas Plant Research Station, Ajitmal.

[21] Dugba, P.N. and Zhang, R. (1999) Treatment of Diary Waste Water with Two Stage Anaerobic Sequencing Batch Reactor Systems-Thermophilic versus Mesophilic Operations. Bioresource Technology, 68, 225-233. http://dx.doi.org/10.1016/S0960-8524(98)00156-4

[22] Veeken, A.H.M. and Hamelers, B.V.M. (2000) Effect of Substrate-Seed Mixing and Leachate Recirculation on Solid Waste Slate Digestion of Biowaste. Water Science and Technology, 41, 225-262.

[23] Yadvika, S., Sreekrishnan, T.R., Kholi, S. and Rana, V. (2004) Enhancement of Biogas Production from Solid Substrates Using Different Techniques_A Review. Bioresource Technology, 95, 1-100.

[24] Rapport, J., Zhang, R., Jenkins, B.M. and Williams, R.B. (2008) Current Anaerobic Digestion Technologies Used for Treatment of Municipal Organic Solid Waste. California Environmental Protection Agency, Sacramento.

[25] Pohland, F.G. and Ghosh, S. (1971) Developments in Anaerobic Stabilization of Organic Wastes-The Two-Phase Concept. Environmental Letters, 1, 255-266.

[26] Vandevivere, P., De Baere, L. and Verstraete, W. (2003) Types of Anaerobic Digesters for Solid Wastes. In: Mata Alvarez, J., Ed., Biomethanization of the Organic Fraction of Municipal Wastes, IWA Press, London, 111-137

[27] Aslanzadeh, S. (2014) Pretreatment of Cellulosic Waste and High Rate Biogas Production. Doctoral Thesis on Resource Recovery, University of Borås, Borås, 1-50.

[28] Paslotathis, S.G. and Girardo-Gomez, E. (1991) Kinetics of Anaerobic Treatment: A Critical Review. Critical Reviews in Environmental Control, 21, 411-490. http://dx.doi.org/10.1080/10643389109388424

[29] Fernandes, T.V., Klaasse Bos, G.J., Zeeman, G., Sander, J.P.M. and Lier, J.B. (2009) Effects of Thermo-Chemical Pretreatment on Anaerobic Biodegradability and Hydrolysis of Lingocellulosic Biomass. Bioresource Technology, 100, 2575-2579. http://dx.doi.org/10.1016/j.biortech.2008.12.012

[30] Heo, N.H., Park, S.C., Lee, J.S. and Kang, H. (2003) Solubilization of Waste Activated Sludge by Alkaline Pretreatment and Biochemical Methane (BMP) Tests for Anaerobic Co-Digestion of Municipal Organic Waste. Water Science and Technology, 48, 211-219.

[31] Izumi, K., Okishio, Y.K., Niwa, C., Yamamoto, S. and Toda, T. (2010) Effects of Particle Size on Anaerobic Digestion of Food Waste. International Biodeterioration \& Biodegradation, 64, 601-608.

[32] Maj Duong, T.H., Smits, M., Vestraete, W. and Carballa, M. (2011) Enhanced Biomethanation of Kitchen Waste by Different Pretreatments. Bioresource Technology, 102, 592-599. http://dx.doi.org/10.1016/j.biortech.2010.07.122

[33] Miah, M.S., Tada, C. and Yang, Y. (2005) Aerobic Thermophilic Bacteria Enhance Biogas Production. Journal of Material Cycles and Waste Management, 7, 48-54.

[34] Rafique, R., Poulsen, T.G., Nizami, A.S., Asamzz, Z.U.Z., Murphy, J.D. and Kiely, G. (2010) Effect of Thermal, Chemical and Thermo-Chemical Pretreatments to Enhance Methane Production. Energy, 35, 4556-4561. http://dx.doi.org/10.1016/j.energy.2010.07.011

[35] Valo, A., Carrere, H. and Delgenes, J.P. (2004) Thermal, Chemical and Thermo-Chemical Pre-Treatments of Waste Activated Sludge for Anaerobic Digestion. Journal of Chemical Technology and Biotechnology, 79, 1197-1203. http://dx.doi.org/10.1002/jctb.1106

[36] Lu, J.,Gavala, H.N., Skiadas, I.V., Mladenovska, Z. and Ahrin, B.K. (2008) Improving Anaerobic Sewage Sludge Digestion by Implementation of a Hyper-Thermophilic Prehydrolysis Step. Journal of Environmental Management, 88, 881-889. http://dx.doi.org/10.1016/j.jenvman.2007.04.020 
[37] Nevers, L., Ribeiro, R., Oliveira, R. and Alves, M.M. (2006) Enhancement of Methane Production from Barley Waste. Biomass and Bioenergy, 30, 599-560. http://dx.doi.org/10.1016/j.biombioe.2005.12.003

[38] Gavala, H.N., Yenal, U., Skiadas, I.V., Westermann, P. and Ahring, B.K. (2003) Mesophilic and Thermophilic Anaerobic Digestion of Primary and Secondary Sludge, Effect of Pretreatment at Elevated Temperatures. Water Research, 37, 4561-4572.

[39] Rozzi, A. and Remigi, E. (2004) Methods of Assessing Microbial Activity and Inhibition under Anaerobic Conditions: A Literature Review. Re/Views in Environmental Science \& Bio/Technology, 3, 93-115. http://dx.doi.org/10.1007/s11157-004-5762-z

[40] Skiadas, I.V., Gavala, H.N., Lu, J. and Ahring, B.K. (2005) Thermal Pretreatment of Primary and Secondary Sludge at $70^{\circ} \mathrm{C}$ Prior to Anaerobic Digestion. Water Science and Technology, 52, 161-166.

[41] Demirel, B. and Yenigun, O. (2002) Two Phase Anaerobic Digestion Processes: A Review. Journal of Chemical Technology and Biotechnology, 77, 743-755. http://dx.doi.org/10.1002/jctb.630

[42] Ghosh, S. and Pohland, F.G. (1974) Kinetics of Substrate Assimilation and Product Formation in Anaerobic Digestion. Journal of Water Pollution Control Federation, 46, 748-759.

[43] Massay, M.L. and Pohland, F.G. (1978) Phase Separation of Anaerobic Stabilization by Kinetics Controls. Journal of water Pollution Control Federation, 50, 2204-2222.

[44] Cohen, A., Zoetemeyer, R.J., Van Deursen, A. and Van Andel, J.G. (1979) Anaerobic Digestion of Glucose with Separated Acid Production and Methane Formation. Water Research, 13, 571-580. http://dx.doi.org/10.1016/0043-1354(79)90003-4

[45] Pohland, F.G. and Mancy, K.H. (1969) Use of pH and pE Measurements during Methane Biosynthesis. Biotechnology and Bioengineering, 11, 683-699. http://dx.doi.org/10.1002/bit.260110412

[46] Fernandes, I.A.P. (1986) Application of Porous Membranes for Biomass Retention in a Two-Phase Anaerobic Process. University of Newcastle, Newcastle upon Tyne.

[47] US EPA Biosolids Technology Factsheet (2006) Multi Stage Anaerobic Digestion. US Environmental Protection Agency, Washington DC, EPA 832-F-806-031.

[48] Schnurer, A. and Jarvis, A. (2009) Microbiological Handbook for Biogas Plant. Swedish Waste Management, Swedish Gas Centre, Malmö, 1-74.

[49] Gerardi, M.H. (2003) The Microbiology of Anaerobic Digesters. Wiley, Hoboken, 89-92. http://dx.doi.org/10.1002/0471468967.ch14

[50] Chandra, R., Takeuchi, H. and Hasegawa, T. (2012) Methane Production from Lignocellulosic Agricultural Crop Wastes: A Review in Context to Second Generation of Biofuel Production. Renewable and Sustainable Energy Reviews, 16, 1462-1476. http://dx.doi.org/10.1016/j.rser.2011.11.035

[51] Deublein, D. and Steinhauser, A. (2008) Biogas from Waste and renewable Resources: An Introduction. Wiley-VCH, Weinheim, 89-290.

[52] Schink, B. (1997) Energetics of Syntrophic Cooperation in Methanogenesis Degradation. Microbiology and Molecular Biology Reviews, 61, 262-280.

[53] Yen, H.W. and Brune, D.E. (2007) Anaerobic Co-Digestion of Algal Sludge and Waste Paper to Produce Methane. Bioresource Technology, 98, 130-134. http://dx.doi.org/10.1016/j.biortech.2005.11.010

[54] Ahring, B., Angelidaki, I., Macario, E.C., Gavala, H.N., Hofman-Bang, J., Macario, A.J.L., Elferink, S.J., Raskin, L., Stams, A.J.M., Westermann, P. and Zheng, D. (2003) Perspective for Anaerobic Digestion. Biomethanation, 81, 1-30. Springer, Berlin and Heidelberg.

[55] Pages Diaz, J., Pereda Reyes, I., Lundin, M. and Sarvari Horvath, I. (2011) Co-Digestion of Different Waste Mixtures from Agro-Industrial Activities: Kinetic Evaluation and Synergetic Effects. Bioresource Technology, 102, 1083410840. http://dx.doi.org/10.1016/j.biortech.2011.09.031

[56] Gunaseelan, V.N. (1997) Anaerobic Digestion of Biomass for Methane Production: A Review. Biomass and Bioenergy, 13, 83-144. http://dx.doi.org/10.1016/S0961-9534(97)00020-2

[57] Barber, N.P. and Stucky, D.C. (1999) The Use of the Anaerobic Baffled Reactor (ABR) for Waste Water Treatment: A Review. Water Research, 33, 1559-1578.

[58] Fannin, K.F. and Biljetina, R. (1987) Reactor Design. In: Chynoweth, D.P. and Isaacson, R., Eds., Anaerobic Digestion of Biomass, Elsevier Applied Science, London, 109-128. 